\title{
Analysis of the relationship between temporomandibular dysfunction and sleep quality: A cross-sectional study
}

\author{
Análise da relação entre disfunção temporomandibular e qualidade do sono: Um estudo transversal \\ Análisis de la relación entre disfunción temporomandibular y calidad del sueño: Un estudio
} transversal

Edilaine Soares Santos ORCID: https://orcid.org/0000-002-7848-8531

Centro Universitário de Rio Preto, Brazil E-mail: dilaine_soares@hotmail.com

Antônio Marcos de Souza Prates ORCID: https://orcid.org/0000-0001-9479-3803 Centro Universitário de Rio Preto, Brazil E-mail:prates.ams@hotmail.com

Fabiele Perpétua Chagas Sabatim Barros ORCID: https://orcid.org/0000-0002-7846-4978 Centro Universitário de Rio Preto, Brazil E-mail: fabielesabatin@ hotmail.com Rachel Silva Lima ORCID: https://orcid.org/0000-0002-1173-3600 Centro Universitário de Rio Preto, Brazil E-mail: rachel_silva_lima@hotmail.com Karolina Nunes Freitas Morais ORCID: https://orcid.org/0000-0002-3109-527 Centro Universitário de Rio Preto, Brazil E-mail: moraiskarol@yahoo.com Henrique Hadad ORCID: https://orcid.org/0000-0001-6446-3643 São Paulo State University, Brazil E-mail: henriquehadad@gmail.com

Valthierre Nunes de Lima ORCID: https://orcid.org/0000-0001-7673-4439 Centro Universitário de Rio Preto, Brazil E-mail: valthierre@hotmail.com

Lamis Meorin Nogueira ORCID: https://orcid.org/0000-0001-5690-8614 Centro Universitário do Norte Paulista, Brazil E-mail: lamisnogueira@gmail.com

\begin{abstract}
Considered as a set of disorders, temporomandibular disorder (TMD) involves several anatomical structures such as the temporomandibular joint, masticatory muscles and attached structures. Its etiology is multifactorial, and the psychobehavioral factor, especially sleep disorders, is relevant in this context. This study aimed to assess the prevalence of temporomandibular dysfunction (TMD), sleep quality, and possible associations between these variables, in first to fifth year students of the Dental School. A sample of 182 students participated in this study and a questionnaire proposed by the American Academy of Orofacial Pain and the Pittsburgh Sleep Quality Index questionnaire were used to obtain the data. $75.27 \%$ of the students were females and $24.72 \%$ males. TMD was observed in $45.60 \%$ of students, and $68.13 \%$ of the students reported poor sleep quality. However, there was no significant association between the variables (TMD and sleep quality, $\mathrm{p}=0.114$ ). Regarding the severity of TMD, the mild form was more prevalent $(34.61 \%)$, being more prevalent in females $(79.16 \%)$. However, there was no significant association between TMD and sleep quality $(\mathrm{p}=0.317)$. There was no association between TMD and sleep quality in the studied population.
\end{abstract}

Keywords: Temporomandibular joint dysfunction syndrome; Sleep; Joint dislocations complications.

\section{Resumo}

Considerada como um conjunto de distúrbios, a disfunção temporomandibular (DTM) envolve diversas estruturas anatômicas como a articulação temporomandibular, músculos mastigatórios e estruturas anexas. Sua etiologia é 
multifatorial, sendo o fator psicocomportamental, principalmente os distúrbios do sono, relevante neste contexto. O objetivo deste estudo foi avaliar a prevalência de disfunção temporomandibular (DTM), qualidade do sono e possíveis associações entre essas variáveis, em estudantes do primeiro ao quinto ano do curso de Odontologia. Participou deste estudo uma amostra de 182 alunos, sendo utilizados para a obtenção dos dados o questionário proposto pela American Academy of Orofacial Pain e o questionário Pittsburgh Sleep Quality Index11. 75,27\% dos alunos eram do sexo feminino e $24,72 \%$ do sexo masculino. A DTM foi observada em 45,60\% dos alunos, sendo que 68,13\% dos mesmos relataram má qualidade de sono. No entanto, não houve associação significativa entre as variáveis (DTM e qualidade do sono, $\mathrm{p}=0,114)$. Em relação à gravidade da DTM, a forma leve foi a mais prevalente $(34,61 \%)$, sendo mais notada no sexo feminino (79,16\%). Todavia, não houve associação significativa entre DTM e qualidade do sono $(\mathrm{p}=0,317)$. Não houve associação entre DTM e qualidade do sono na população estudada.

Palavras-chave: Síndrome da disfunção da articulação temporomandibular; Sono; Complicações das luxações articulares.

\section{Resumen}

Considerado como un conjunto de trastornos, el trastorno temporomandibular (TTM) involucra varias estructuras anatómicas como la articulación temporomandibular, los músculos masticatorios y las estructuras adheridas. $\mathrm{Su}$ etiología es multifactorial y el factor psicoconductual, especialmente los trastornos del sueño, es relevante en este contexto. El objetivo de este estudio fue evaluar la prevalencia de trastornos temporomandibulares (TTM), la calidad del sueño y las posibles asociaciones entre estas variables, en estudiantes del primero al quinto año de la carrera de Odontología. Una muestra de 182 estudiantes participó en este estudio, utilizando el cuestionario propuesto por la Academia Americana de Dolor Orofacial y el Índice de Calidad del Sueño de Pittsburgh11 para obtener los datos. $75,27 \%$ de los estudiantes eran mujeres y el 24,72\% hombres. Se observó TMD en el 45,60\% de los estudiantes, y el $68,13 \%$ de ellos informaron una mala calidad del sueño. Sin embargo, no hubo asociación significativa entre las variables (DTM y calidad del sueño, $\mathrm{p}=0,114$ ). En cuanto a la gravedad de los TTM, la forma leve fue la más prevalente $(34,61 \%)$, siendo más notoria en el sexo femenino $(79,16 \%)$. Sin embargo, no hubo asociación significativa entre TMD y calidad del sueño $(\mathrm{p}=0.317)$. No hubo asociación entre TMD y calidad del sueño en la población estudiada.

Palabras clave: Síndrome de disfunción de la articulación temporomandibular; Sueño; Complicaciones de luxaciones articulares.

\section{Introduction}

Temporomandibular dysfunctions (TMD) as defined by the American Academy of Orofacial Pain (AAOP) include a set of disorders involving various structures of the stomatognathic system, such as the temporomandibular joint (TMJ) and masticatory muscles (Carrara et al, 2010). Among the signs and symptoms reported by the patients, the most prevalent are the cracking sound during opening and closing of the mouth, pain at the TMJ and adjacent area, muscle fatigue, headaches, limited mouth opening, and hearing disorders (Pinto et al, 2017).

The etiology of TMD is multifactorial and involves an interaction between biopsychosocial, neuromuscular, biomechanical, and biological factors. The correlation between variety of signs and symptoms and etiology is unclear. In terms of biopsychosocial etiology, studies have shown some emotional factors, such as anxiety, depression, stress, mood fluctuations, and sleep disorders contribute to TMJ disorders (Pinto et al, 2017; Zwiri et al, 2020; Jariyasakulroj \& Mitrirattanakul, 2020).

Studies on quality of sleep have shown a bidirectional association between TMD and sleep disorders (Almoznino et al, 2017). Usually, this relationship is based on TMD symptoms, especially pain, which increases the individual's degree of mental and physical commitment (Ton et al, 2020). In addition, other factors, such as stress and anxiety, have also been reported to affect this relationship (Tonial et al, 2014).

In a university environment, both TMD and sleep disorders are common. Due to continuous curricular activities and extra-curricular tasks, many students are unable to maintain a balance between their physical and mental well-being and academic obligations. It is worth mentioning that these aspects may increase with the complexity of the academic degree being pursued (Tonial et al, 2014; Correia et al, 2017; Benassi et al, 2020). 
Thus, the objective of this study was to evaluate the prevalence of TMD and assess sleep quality in first to fifth year students of the Centro Universitário de Rio Preto-UNIRP Dental School, and to verify whether there is an association between these variables.

\section{Methodology}

\subsection{Ethical Statement}

This study was submitted to and approved by the Research Ethics Committee (CEP protocol number 3.141.244) at the Centro Universitário de Rio Preto (UNIRP).

\subsection{Data Tools}

For this study, two questionnaires were used: the one proposed by the American Academy of Orofacial Pain (AAOP) (Chaulagain \& Maharjan, 2019) and the Pittsburgh Sleep Quality Index (PSQI) questionnaire (Bertolazi et al, 2011). Students were asked to complete both the questionnaires in August, September, and October 2019. In the AAOP questionnaire, scores were assigned a modified scoring system based on the Fonseca Anamnestic Index (was used. Thus, the total scores of the 10 questions ranged from 0 to 100; for each question, "Yes" corresponded to 10 points and "No" to 0 points. Participants were classified according to this score into TMD-free (0 to 10 points), mild TMD (20 to 40 points), moderate TMD (50 to 60 points), and severe TMD (70 to 100 points) groups.

The questionnaire to assess sleep quality included 9 questions. It assesses seven components: subjective sleep quality, sleep delay, sleep duration, usual sleep efficiency, sleep disorders, use of sleeping medications, and daytime dysfunctions. Each component can vary from 0 to 3 points, with " 0 " being an indication of "very good," "1, good"; " 2 , bad"; "3, very bad". The analysis of these components results in the Global PSQI score, which ranges from 0 to 21 points, with a score greater than 5 indicative of poor sleep quality (Bertolazi et al, 2011; Nishikawa et al, 2020).

\subsection{Sample Selection}

The sample was selected for convenience according to the availability of students at the Centro Universitário de Rio Preto-UNIRP, São Paulo, Brazil. Only 182 students out of 250 enrolled in the Dentistry Undergraduation agreed to participate in participated in this research after signing an informed and free consent form. The exclusion criteria included those who were not matriculated in the course, did not want to participate, or did not sign the consent form. Therefore, the sample included students participating in a variety of curricular and extra-curricular activities. Participants were divided into five groups. Therefore, G1 corresponds to first year students, G2 - second year students; G3 - third year students; G4 - fourth year students; and G5 - fifth year students (Figure 1). 
Figure 1 - Groups division according to the year attended and activities developed.

\begin{tabular}{ll}
\hline \multicolumn{1}{c}{ GROUP } & \multicolumn{1}{c}{ ACTIVITIES } \\
\hline Group 1 (G1): 1st year & Most of them are theoretical activities \\
Group 2 (G2): 2nd year & $\begin{array}{l}\text { In addition to theoretical activities, the number of } \\
\text { laboratory acticities increases. }\end{array}$ \\
Group 3 (G3): 3rd year & $\begin{array}{l}\text { Start of clinical activities, but still have } \\
\text { theoretical and laboratory activities. }\end{array}$ \\
Group 4 (G4): 4th year & $\begin{array}{l}\text { A considerabel workload of clinical activities, } \\
\text { and a greater responsability to planning the } \\
\text { treatments in a comprehensive and } \\
\text { multidisciplinar manner. } \\
\text { In addition to all university workload, they are } \\
\text { about to finish their graduation and enter the job } \\
\text { market. }\end{array}$ \\
\hline
\end{tabular}

Source: Authors.

After data collection, the results were tabulated and analyzed using the SigmaPlot 12.0 program; a chi-square test was utilized, considering a significance level of $\mathrm{p}<0.05$.

\section{Results}

In the sample of 182 participants, $138(75.8 \%)$ were female students and $44(24.2 \%)$ were male. The average age of these students was 21.8 years.

In terms of TMD prevalence, it was possible to verify the presence of TMD in 83 participants (45.6\%), with 67 (80\%) women and 16 (20\%) men. The highest prevalence was observed in G4 and G5, which together represented $49.9 \%$ of the total sample with TMD symptoms.

When assessing the correlation between severity of TMD and gender, mild subtype was more prevalent in women than in men (Table 1). However, there was no significant association between the variables $(\mathrm{p}=0.371)$.

Table 1 - Temporomandibular Dysfunction severity, according to sex in the university students. São José do Rio Preto, SP Brazil, 2019.

\begin{tabular}{cccccc}
\hline \multicolumn{5}{c}{ Temporomandibular Dysfunction } \\
\hline \multirow{2}{*}{ Women } & $138(100 \%)$ & $71(51.4 \%)$ & $48(34.7 \%)$ & $13(9.4 \%)$ & Severe \\
\multirow{2}{*}{ Men } & $44(100 \%)$ & $28(63.6 \%)$ & $15(34.0 \%)$ & $0(0 \%)$ & $6(4.3 \%)$ \\
\hline \multicolumn{5}{c}{ Source: Authors. }
\end{tabular}

Students who experienced TMD symptoms were between 18 and 47 years old (Table 2). Compared to that of the other groups, G1 showed a significant variation in age, and G5 had the lowest variation, but the highest average age. 
Table 2 - Average and age variation of university students with Temporomandibular Dysfunction symptoms. São José do Rio Preto, SP - Brazil, 2019.

\begin{tabular}{cccc}
\hline Group & TMD & Age Variation & Average of ages \\
\hline G1 & 16 & $18-47$ & 21.5 \\
G2 & 12 & $18-31$ & 21 \\
G3 & 16 & $19-36$ & 21.6 \\
G4 & 20 & $20-33$ & 22.3 \\
G5 & 19 & $21-26$ & 22.6 \\
Total & 83 & $17-47$ & 21.8 \\
\hline
\end{tabular}

Note: *TMD: temporomandibular dysfunction. Source: Authors.

Concerning the results obtained using the PSQI questionnaire, around $68 \%$ of the students had a PSQI score $>5$ and were characterized as poor sleepers (Figure 2). However, when the students were asked about how they would rate the quality of their sleep, during the last month, more than half of the participants marked the option "Good" (Figure 3).

Figure 2 - Global Pittsburgh Sleep Quality Index (PSQI) Score in university students. São José do Rio Preto-SP Brazil, 2019.

\section{Global PSQI Score}

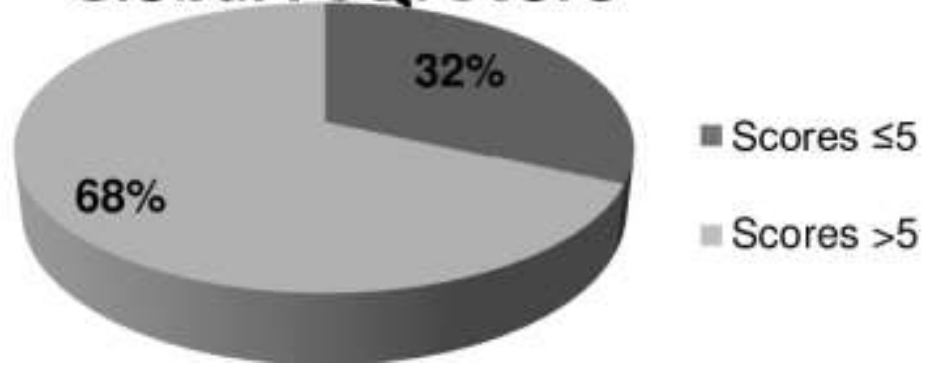

Source: Authors.

Figure 3 - Subjective Sleep Quality in university students. São José do Rio Preto-SP, Brazil, 2019.

\section{6\% Subjective Sleep Quality}

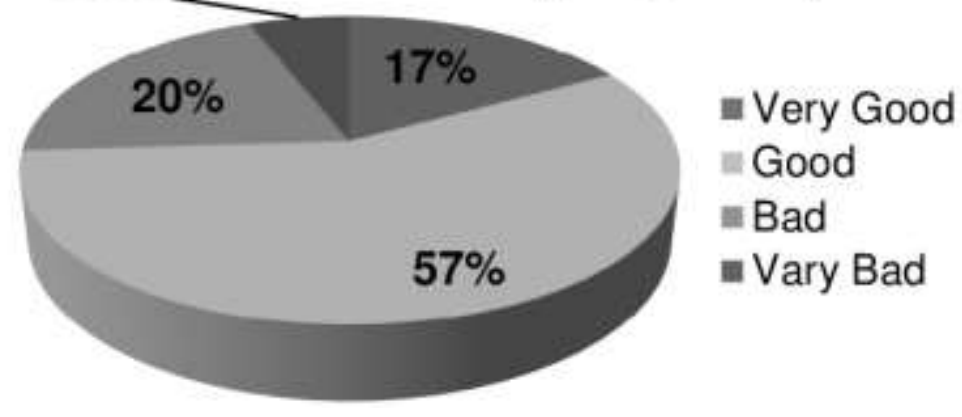

Source: Authors.

Thirty-nine students reported experiencing difficulty in sleeping in PSQI questionnaire administered in the last month due to reasons such as anxiety, insomnia, nervousness, coffee ingestion, concerns about the college, tests and use of technologies. Among these, the most popular was anxiety, with the most frequent occurrence, 3 or more times a week 
experience difficult sleeping.

In the PSQI questionnaire, some values were more expressive, such as sleep latency and daytime dysfunction (Table 3). The former pertains to difficulty in sleeping, and the latter pertains to difficulty in staying awake and maintaining enthusiasm during their usual activities. The average time taken by university students to sleep was approximately 27 minutes and the number of sleep hours was 6 hours and 40 minutes.

Table 3 - Average of PSQI components in university students. São José do Rio Preto-SP, Brazil,2019.

\begin{tabular}{ccccccccc}
\hline & SQ & SL & SD & USE & SA & UM & $\begin{array}{c}\text { DD } \\
\text { PSQI } \\
\text { index }\end{array}$ \\
\hline G1 & 1.2 & 1.6 & 1.1 & 0.3 & 1.2 & 0.3 & 1.5 & 7.2 \\
G2 & 1.3 & 1.6 & 0.9 & 0.3 & 1.3 & 0.3 & 1.4 & 7 \\
G3 & 1.0 & 1.3 & 0.8 & 0.2 & 1.4 & 0.5 & 1.3 & 6.7 \\
G4 & 1.2 & 1.3 & 1.0 & 0.1 & 1.1 & 0.5 & 1.5 & 6.7 \\
G5 & 1.0 & 1.6 & 0.9 & 0.3 & 1.1 & 0.5 & 1.3 & 6.7 \\
\hline
\end{tabular}

Note:* PSQI: Pittsburgh Sleep Quality Index, SQ: Sleep Quality, SL: Sleep Latency, SD: Sleep Duration, USE: Usual Sleep Efficiency, SA: Sleep Alteration, UM: Use of Medication and DD: Daytime Dysfunction. Source: Authors.

Based on the results of both questionnaires, no correlation was seen between TMD symptoms and poor sleep quality (PSQI score >5). The most significant numbers in the PSQI questionnaire were in G4 and G5, regarding mild TMD (Figure 4). The moderate classification was not found in groups G4 and G5, only in groups G1, G2, and G3. The severe classification was more concentrated in G3. Thus, the moderate and severe types of TMD were more prevalent in the groups corresponding to the initial years of studies.

Figure 4 - Participants by group according to the degree of severity with poor sleep quality and symptoms of Temporomandibular Dysfunction.

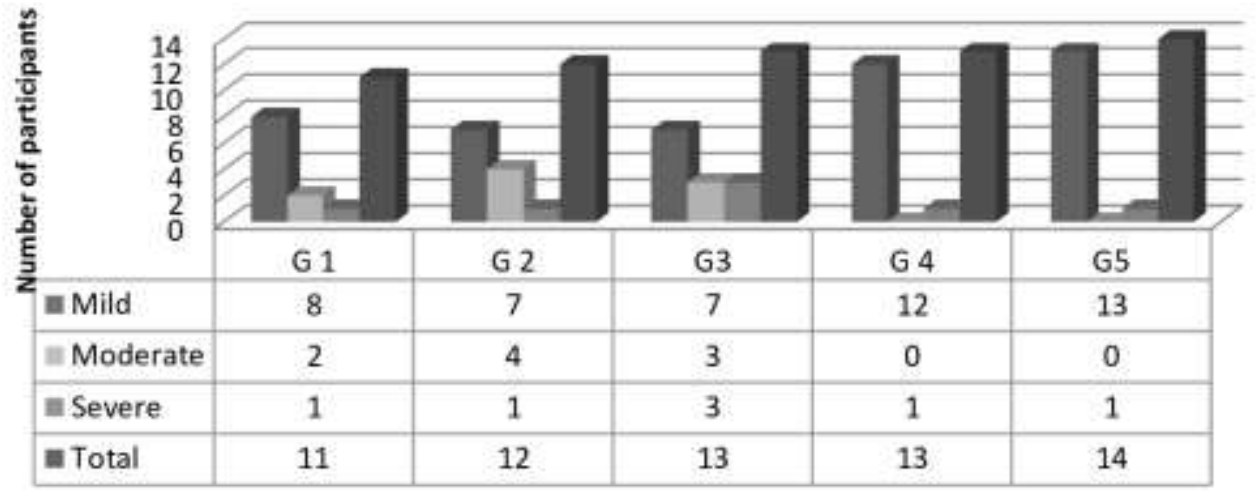

Source: Authors.

\section{Discussion}

The specific research population was undergraduate dental students; they were included due to their propensity for developing both TMD and sleep disorders. This occurs because of their daily exposure to factors, such as stress and anxiety (Ton et al, 2020), that predispose and perpetuate these disorders. According to Bezzera et al (2012), individuals, such as health 
professionals and academicians, are prone to developing psychological disorders, which according to Khatoon et al (2020), induce the development of muscle hyperactivity and overuse of the TMJ, which contributes to the occurrence of TMDs.

Data were collected exclusively through questionnaires, which are easy to use and aid anamnesis during prescreening. However, it has a subjective nature, requiring verification with a clinical examination. So, when performed, would increase the veracity of the symptoms, but would cause a decrease in the number of participants (Selms et al, 2020).

We observed that $80 \%$ of the 83 students with TMD symptoms were women. However, the association between the variables was not significant ( $\mathrm{p}=0.297$ ). Aguilera et al (2014), Reyad et al (2020), and Ton et al (2020) reported similar findings in their studies, $89.4 \%, 72.7 \%$, and $76.35 \%$, respectively. The literature explains that the high prevalence among females is linked to hormonal factors, such as estrogen. There is evidence that estrogen levels affect pain modulation, inflammatory response, metabolism, development, and restitution of TMJ components and associated structures (Ferreira et al, 2016).

Out of the $68.63 \%$ of students who had TMD, Ton et al, (2020) diagnosed mild TMD in $46.9 \%$ of the students. The present study had similar findings, but the observed prevalence was $76 \%$; however, there was no significant association between the variables $(\mathrm{p}=0.371)$. As for the moderate and severe forms, they were prevalent in women, as in other studies (Bezerra et al, 2012; Oliveira et al, 2006).

Regarding the evaluation by the PSQI questionnaire, $57 \%$ of the students declared that they had a good quality of sleep, which contradicts the final result of the PSQI questionnaire, where a score greater than 5 was reported in $68 \%$ of the sample. Araújo et al (2013) found that $54 \%$ of the participants classified their sleep quality as poor, but an overall score greater than 5 was reported by $95.3 \%$ of the participants. This statement may be linked to the lack of self-perception of sleep quality in students.

The highest average scores in the PSQI questionnaire were for sleep latency and disorder. The first is supposed to be associated with use of technology, especially the internet, which affects sleep time, especially when used during the night or vacant periods that students reserve to enjoy services such as social networks and streaming service for films and series (Araújo et al, 2013). Studies indicate that daytime sleepiness due to sleep disorders is capable of impairing school performance, as it negatively influences the function of the hippocampus and the prefrontal cortex, causing a deficit in logical reasoning, memory, creativity, and language (Shammari et al, 2020).

Approximately $21 \%$ of university students reported using medication to sleep. Usage of medications, especially by young people, is commonly linked to an attempt to deal with sleep problems caused by internet addiction and/or negative emotions, such as anxiety, interpersonal sensitivity, and depression (Lin et al, 2019).

The presence of TMD symptoms and poor sleep quality was found in $34.6 \%$ of the students. However, there was no significant association between the variables $(\mathrm{p}=0.114)$. When assessing sleep quality in university students with TMD symptoms, $75.9 \%$ students were found to have poor sleep quality and TMD symptoms. Corroborating the findings of a study by Drabovic et al (2012) who investigated the occurrence of poor sleep-in adolescents with TMD and observed that $41 \%$ of the sample had both symptoms.

Although there is no relationship between sleep and TMD in the G4 and G5, it is important to note that these groups participated in the highest number of curricular activities and had an extensive workload that largely involved clinical activities. Martins et al (2010) also found this relationship in 53.3\% of 180 patients with TMD and claimed that both may be related to daily stress and events that require readjustment of the individual.

In the other groups, where it was possible to verify reports of emotional disorders, the degree of severity of the TMD most commonly found was mild. However, different studies have declared that emotional disorders increase as the degree of severity of the pathology increases (Pinto et al, 2017; Natu et al, 2018). 
The literature reports that situations of psychological impact increase the prevalence of anxiety in the population. According to Leite et al (2020), the COVID-19 pandemic worsened the mental health of patients with TMD and there will certainly be post-pandemic effects, such as an increase and worsening of these cases. In this scenario, dentists must use individualized strategies, while considering the multifactorial etiology. They should adapt to individual circumstances and utilize various treatment methods, including sleep hygiene management, physical exercise, self-massage, and "teledentistry" (Oliveira et al, 2020).

Therefore, it is suggested that university students of dental school, given their vulnerability to such dysfunctions, be included in the planning of approaches for the prevention of onset and worsening of TMD.

Although the literature has demonstrated a strong relationship between sleep quality and TMD (Sanders et al, 2013; Truong et al, 2020) the authors believe that this relationship was not observed in this study due to the size of the studied population. It is important to highlight that this study has certain limitations, such as the absence of clinical and complementary tests that confirmed the diagnosis in the studied sample. However, the instruments used to collect the data can be considered relevant for screening because of their ease of application and acceptability in the research community.

\section{Conclusion}

The study data do not suggest an association between the presence of TMD and poor sleep quality in the studied sample. More research on this topic is necessary to prove whether there is a relationship between TMD and sleep quality.

\section{References}

Blanco-Aguilera, A., Blanco-Hungría, A., Biedma-Velázquez, L., Serrano-Del-Rosal, R., González-López, L., Blanco-Aguilera, E., \& Segura-Saint-Gerons, R. (2014). Application of an oral health-related quality of life questionnaire in primary care patients with orofacial pain and temporomandibular disorders. Medicina oral, patologia oral y cirugia bucal, 19(2), e127-e135. https://doi.org/10.4317/medoral.19061

Almoznino, G., Benoliel, R., Sharav, Y., \& Haviv, Y. (2017). Sleep disorders and chronic craniofacial pain: Characteristics and management possibilities. Sleep medicine reviews, 33, 39-50. https://doi.org/10.1016/j.smrv.2016.04.005

Araújo, M. F. M., Lima, A. C. S., Alencar, A. M. P. G., Araújo, T. M., Fragoaso, L. V. C., \& Damasceno, M. M. C (2013). Sleep quality assessment in college students from Fortaleza-CE. Text \& Context Nursing, 22(2), 352-360. 10.1590/S0104-07072013000200011

Benassi, G. F., Mariotto, L. G. S., Botelho, A. L., Valente, M. L. C., \& Dos Reis, A. C. Relationship between temporomandibu- lar dysfunctions, sleep disorders, and anxiety among dentistry students (2020). Journal of Craniomandibular \& Sleep Practice, 38(1), 1-4. 10.1080/08869634.2019.1708609

Bertolazi, A. N., Fagondes, S. C., Hoff, L. S., Dartora, E. G., Miozzo, I. C. S., Barba, M. E. F., \& Barreto, S. S. M (2011). Validation of the Brazilian Portuguese version of the Pittsburgh Sleep Quality Index. Sleep Medicine, 12(1), 70-75. 10.1016/j.sleep.2010.04.020

Bezerra, B. P. N., Ribeiro, A. I. A. M., de Farias, A. B. L., Fontes, L. B. C., Nascimento, S. R., Nascimento, A. S., \& Adriano M. S. P. F. et al (2012). Prevalence of temporomandibular joint dysfunction and diferente levels of anxiety among college students. Revista Dor, 13(3), 235-242. 10.1590/S180600132012000300008

Bourzgui, F., Benlabsir, H., Serhier, Z., Diouny, S., \& Othmani, M. B. (2019). Assessment of Temporomandibular Dysfunction and Stress in Moroccan Dental Students. EC Dental Science, 18(6), 1260-1269

Carrara, S. V., Conti, P. C. R., \& Barbosa, J. S. (2010). Statement of the 1st Consensus on temporo-mandibular Disorders and Orofacial Pain. Dental Press Journal Orthodontics. 15(3), 114-120. 10.1590/S2176-94512010000300014

Chaulagain, R., \& Maharjan, A. (2019). Prevalence of Temporomandibular Joint Disorders and its Association with Para Functional Habits in the Patients Attending Tertiary Care Hospital. Journal of Nepal Health Research Council, 17(3), 376-381. 10.33314/jnhrc.v17i3.2126

Corrêa, C. C., Oliveira, F. K., Pizzamiglio, D. S., Ortolan, E. V. P., \& Weber, S. A.T.(2017). Sleep quality in medical students: a comparison across the various phases of the medical course. Jornal Brasileiro de Pneumologia, 43(4), 285-289. 10.1590/s1806-37562016000000178

Drabovicz, P. V. S. M., Salles, V., Drabovicz, P. E. M., \& Fontes, M. J. F. (2012). Assessment of sleep quality in adolescentes with temporomandibular disorders. Journal of Pediatrics, 88(2), 169-172. 10.2223/JPED.2180

Ferreira, C. L. P., da Silva, M. A. M. R., \& Felício, C. M. (2016). Signs and symptoms of temporomandibular disorders in women and men. Communication Disorders, Audiology and Swallowing, 28(1), 17-21. 10.1590/2317-1782/20162014218

Jariyasakulroj, S., \& Mitrirattanakul, S. (2020). Excessive daytime sleepiness in temporomandibular disorder patients. Journal of Craniomandibular \& Sleep Practice, 38(3), 144-148. 10.1080/08869634.2018.1525116 
Khatoon, S., Suresh, S., Ilyas, M., Rani, P., Khokhar, M., \& Ahmed, S. (2020). Evaluate of the prevalence and severity of symptoms of temporomandibular joint dysfunction (TMJD). Professional Medical Journal, 27(6), 1157-1164. doi.org/10.1590/S1806-83242006000100002

Leite, C. M. A., Barbosa, J. S., \& Conti, P. C. R. (2020). How psychosocial and economic impacts of COVID-19 pandemic can interfere on bruxism and temporomandibular disorders?. Journal of Applied Oral Science, 28:e20200263, 1-3. 10.1590/1678-7757-2020-0263

Lin, P. H., Lee, Y. C., Chen, K. L., Hsieh, P. L., Yang, S. Y., \& Lin, Y. L.(2019). The Relationship Between Sleep Quality and Internet Addiction Among Female College Students. Frontiers in Neuroscience, 13(599), 1-9. 10.3389/fnins.2019.00599

Martins, R. J., Garbin, C. A. S., Garcia, A. R., Garbins, A. J. I., \& Miguel, N. (2010). Stress levels and quality of sleep in subjects with temporomandibular joint dysfunction. Revista odonto ciência, 25(1), 32-36. 10.1590/S1980-65232010000100007

Natu, V. P., Yap, A. U., Su, M. H., Ali, N. M., \& Ansari, A. (2018). Temporomandibular disorder symptoms and their association with quality of life, emotional states and sleep quality in SouthEast Asian youths. Journal of Oral Rehabilitation, 45(10), 756-763. 10.1111/joor.12692

Nishikawa, H., Yoh, K., Enomoto, H., Iwata, Y., Nishimura, T., Nishiguchi, S., \& Lijima, H. (2020). Frailty and Sleep Disorder in Chronic Liver Diseases. Journal Life, 10(8), 137. 10.3390/life10080137

Oliveira, A. S., Dias, E. M., Contato, R. G., \& Berzin, F. (2006). Prevalence study of signs and symptoms of temporomandibular disorder in Brazilian college students. Brazilian Oral Research, 20(1), 3-7. 10.1590/S1806-83242006000100002

Oliveira, S. S. I., Gonçalves, S. L. M., Weig, K. M., Magalhães Filho, T. R., Martinez, O. E. R., Kalil, M. T. A. C., \& Boggiss, G. P. et al. (2020). Temporomandibular disorders: Guidelines and Self-Care for Patients During COVID-19 Pandemic. Brazilian Dental Science, 23(2), 1-8.

Pinto, R. G. S., Leite, W. M. A., Sampaio, L. S., \& Sanchez, M. O. (2017). Association between temporomandibular signs and symptoms and depression in undergraduate students: descriptive study. Revista Dor, 18(3), 217-224. 10.5935/1806-0013.20170105

Reyad, J. M., Mohammed, J. M., Susan, A. N., \& Abdallah, R. A. (2020). Prevalence of temporomandibular disorders among Palestinian medical students. World Journal of Advanced Research and Reviews, 06(01), 146-152. 10.30574/wjarr.2020.6.1.0074

Sanders, A. E., Essick, G. K., Fillingim, R., Knott, C., Ohrbach, R., Greenspan, J. D., \& Slade, G. D. (2013). Sleep apnea symptoms and risk of temporomandibular disorder: OPPERA cohort. Journal of Dental Research, 92(7), S70-S77. 10.1177/0022034513488140

Selms, M. K. A. V., Wiegers, J. W., Hedwig, M. V. A., Ahlberg, J., Lobbezoo, . F., \& Visscher, C. M. (2020). Temporomandibular disorders, pain in the neck and shoulder area, and headache among musicians. Journal of Oral Rehabilitation, 47(2), 132-142. 10.1111/joor.12886

Shammari, M. A. A., Amer, N. A., Mulhim, S. N., Mohammedsaleh, H. N., \& Omaar, R. S. (2020). The quality of sleep and daytime sleepiness and their association with academic achievement of medical students in the eastern province of Saudi Arabia. Journal of Family \& Community Medicine, 27(2), 97-102. 10.4103/jfcm.JFCM_160_19

Ton, L. A. B., Mota, I. G., de Paula, J. S. \& Martins, A. P. V. B. (2020). Prevalence of temporomandibular disorder and its association with stress and anxiety among university students. Brazilian Dental Science, 23(1), 1-9

Tonial, L. F., Stechman Neto, J., \& Hummig, W. (2014). Chronic pain related to quality of sleep. Journal Einstein, 12(2), 159-163. 10.1590/S167945082014AO2825

Truong, L., Reher, P., \& Doan, N. (2020). Correlation between upper airway dimension and TMJ position in patients with sleep disordered breathing. Journal of Craniomandibular \& Sleep Practice. 8, 1-9. 10.1080/08869634.2020.1853465

Zwiri, A., Al-Hatamleh, M. A. I., W- Ahmad, W. M. A., Ahmed Asif, J., Khoo, S. P., Husein, A., \& Kassim N. K. (2020). Biomarkers for Temporomandibular Disorders: Current Status and Future Directions. Journal from Multidisciplinary Digital Publishing Institute, 10(5), 1-18. 10.3390/diagnostics10050303 